\title{
Women entrepreneurs: Discussion about their competencies
}

\author{
Vânia Maria Jorge Nassif ${ }^{1 *}$, Tales Andreassi ${ }^{2}$, Maria Jose Tonelli ${ }^{2}$ and \\ Maria Tereza Leme Fleury ${ }^{2}$
}

\author{
${ }^{1}$ Programa de Pós-Graduação Stricto-Sensu da Uninove; Programa de Pós-Doutorado da FGV-EAESP de SP, Brasil \\ ${ }^{2}$ FGV - EAESP Escola de Administração de Empresas de São Paulo, Brasil
}

Accepted 29 August, 2011

\begin{abstract}
The aim of this research is to analyze the entrepreneurial competencies that characterize women in the Southeast region of Brazil, who face some financial limitations in relation to the day-to-day challenges of their businesses. The research is classified as exploratory, intending to explain the phenomenon studied based on the point of view of the research subjects. Seven female participants were involved in an entrepreneurship program in São Paulo city and financed by an American bank. Data were collected by means of in-depth interviews, followed by a flexible questionnaire. The data analysis was based on the content analysis and classified into three blocks: Category 1 - decisive factors in beginning the business; Category 2 - challenges and obstacles in the entrepreneurial career; Category 3 competencies developed and under development during the trajectory. The results reveal that female entrepreneurs have a perception of their potentialities, limitations, desires and concerns within a scope of cognitive and affective competencies. They recognize the importance of developing perception of opportunity, business and applying leadership competencies. Interpersonal skills, commitment and social perception are sets of entrepreneurial competencies that contribute to their businesses. It is evident that although fragmented in theory, cognitive and affective aspects are, in practice, indissociable.
\end{abstract}

Key words: Women entrepreneurs, competencies, cognitive, affective aspects.

\section{INTRODUCTION}

Studies on entrepreneurship and the entrepreneur have covered a space of unquestionable significance as they exercise a fundamental role in the vision, conduction and action of businesses in different sectors of the global economy (Steyaert, 2007). In this sense, the study of entrepreneurship has grown in complexity through seeking to examine matters that relate it to the social, political and work context, besides the themes linked to individual aspects of what it takes to be an entrepreneur. Questions linked to the activities executed by entrepreneurs, their role as differentiated from that of leader, the distinction between the role of the entrepreneur in relation to that of the manager, as well as

*Corresponding author. E-mail: vania.nassif@uol.com.br. gender issues, have all been researched in recent decades (Gartner, 1985; Filion, 1999b; Steyaert, 2007; Mitchelmore and Rowley, 2010; Minniti, 2009).

Despite recent advances, entrepreneurship research has revealed a field of study replete with academic controversy (Bygrave and Hofer, 1993), marked by an almost complete absence of consensus (Amit et al., 1993) and characterized by a high degree of fragmentation (Ucbasaran et al., 2001). Alongside, this scenario of controversy and intellectual clashes, a consensual vision seems to emerge: that what is lacking in the study of entrepreneurship is a solid, robust theoretical framework, that is, a theoretical base is missing in such studies (Bygrave, 1989; Bygrave and Hofer, 1991; Amit et al., 1993). Danjou (2002) states that the multidimensional concept, which presents the entrepreneur interacting with the environment and acting 
in a dialogic manner, allows a distinct vision of the reductionist format that regards it as merely the act of opening of a company or as intervention in its functional exercise. Thus, the emergence of diverse lines of thinking seems to have been the naturally expected result of the development process of the researches about entrepreneurship. The research available about entrepreneurship has the particularity of gathering ideas of scholars in the social and human sciences; it is currently presented as an area of study in evolution, and displays emerging themes that have been arousing interest among researchers, such as, entrepreneurship and gender. In this field, part of the international researches entails studies about economic development, critical factors and action of female entrepreneurs (Faraha, 2009; Bertaux and Crable, 2007; Botha et al., 2006), training programs and risk capital (Joshi, 2009; Botha et al., 2006), ascension of women as entrepreneurs in the world of work, typology, characteristics and types of businesses run by female entrepreneurs; enterprises that is of necessity are run by women (lakovidou et al., 2009; Hossain et al., 2009; Beauchesne, 1999).

The Brazilian researches, though scarce, constitute studies on identities of female entrepreneurs (Machado, 2009); characteristics, considerations and understanding of female entrepreneurs (Silveira et al., 2008); female entrepreneurs in the field of pedagogy (Novaes et al., 2008); motivation (Moraes, 2008); profile of female entrepreneurs in conducting their own businesses (Gomes, 2004); women entrepreneurs in the technological sector (Jonathan, 2001); time factor, organization and dedication of female entrepreneurs (Gimenez et al., 1998). This article which forms part of a more comprehensive project on the question of female entrepreneurs, has the objective of analyzing the entrepreneurial competencies that, with some financial limitations, characterize women in SE Brazil. The results of this research contribute to the theoretical field of entrepreneurship with the inclusion of affective aspects which are not present in the conceptual framework of Man and Lau (2000). Besides this, they present specific questions regarding Brazilian female entrepreneurs in the face of quotidian challenges in their businesses, which result from their trajectories, built throughout their social interaction.

\section{THEORETICAL FRAMEWORK}

\section{Female entrepreneurs}

The participation of women in the Brazilian labor market has increased significantly, rising from 55.1 to $56.4 \%$, between 2007 and 2008, according to a study by the Fundação Sistema Educacional de Análise de Dados do Estado de São Paulo (SEADE) and Departamento
Intersindical de Estatística e Estudos Socioeconômicos (DIEESE). Data from Appelbaum et al. (2003) shows that women comprise $46.5 \%$ of the world's labor force. The Síntese de Indicadores Sociais (SIS) of the Instituto Brasileiro de Geografia e Estatística (IBGE, 2009) informs that, in ten years, this participation in Brazil has grown from 42 to $47.2 \%$. Fundação (2009) also stated that this increase has occurred in all age groups, at all schooling levels, in all races and positions in the household, but, in particular, women in the range 50 to 59 who possess at least complete fundamental education, husbands/partners and children.

In Brazil, women constitute $51 \%$ of the population (IBGE, 2009). This same report points out that the participation of women in the Brazilian labor market has reached $47.2 \%$. On the other hand, data from Instituto Ethos (2007) shows that women occupy only $10.6 \%$ of the positions at executive level, $31 \%$ of those at managerial level, $27 \%$ of those as (sector/section/dept./area) heads and $32.6 \%$ of those in the functional area. The research further reveals that the fact that women present better schooling levels than men, does not seem to contribute significantly to their ascension to higher company positions. In the United States, the situation does not seem to be so different, as women represent $11.7 \%$ of the director corps in the 500 companies cited by Fortune (Appelbaum et al., 2003). The Global Entrepreneurship Monitor (GEM) (2008) research reveals that, in 2007, Brazilian women occupied 7th place in the world ranking of female entrepreneurs, with $12.71 \%$ (approximately 8 million women). In São Paulo, female entrepreneurs are the 10th most active in the world, or $9.61 \%$ of the women interviewed, representing around 5.5 million female entrepreneurs at an initial stage (with businesses in the set-up phase or in existence for up to 42 months). Ahead of Brazil are: Peru $(26.06 \%)$, Thailand (25.95\%), Colombia (18.77\%), Venezuela (16.81\%), Dominican Republic (14.50\%) and China (13.43\%). In the last places are Latvia (1.41\%), Russia (1.64\%), Austria (1.84\%), Belgium (1.98\%) and France $(2.21 \%)$.

Thus, the focus on the role of women as female entrepreneurs, due to the fact that they acquire spaces in the labor market, has attracted attention, not only in terms of the working conditions to which they are submitted, the well-known double working day, which includes innumerable responsibilities assumed in the family sphere, but above all, in terms of their performance and results achieved. In emerging or developing countries, this question of female entrepreneurs includes still other dimensions. A study conducted in Ethiopia by Bekele and Jacobs (2008) about female entrepreneurs running micro and small firms reveals that the degree of recognition and government support provided to the sector is inadequate. As a counterpart, a research coordinated by the World Bank (2005), the World Trade Organization (2002) and the Ministry of Finance and 
Economic Development of Ethiopia (2002), concluded that female entrepreneurs, even without support and resources, make their businesses grow at twice the rate of those run by men. These institutions consider that the survival of an enterprise is determined by its skill in operating and remaining in the market for a certain period.

Bertaux and Crable (2007) conducted research in a region of India, whose objective was to understand how socio-economic development occurs in that country, especially in some regions of the rural zone, with emphasis on the work of female entrepreneurs. Despite the day-to-day difficulties and restrictions, the research showed encouraging data about economic development which in some regions of the country, arise from the entrepreneurial activities of women. The study also shows that women conciliate in an exemplary manner with their domestic activity, besides contributing to the family budget. In addition, the work done by Botha et al. (2006) in South Africa points out that one of the difficulties encountered by women who want to be entrepreneurs is the precariousness of education and absence of training. The authors of this research developed a program entitled Women Entrepreneurship Programme involving 180 women, 116 being direct participants and 64 participants in the control group, the objective was to evaluate if the capacity for skill and competency transfer was affected by the intervention of training. The results provided evidence that women participants in the program developed skills and acquired new knowledge that helped them to run their businesses more effectively, increasing confidence both in themselves and their work, increasing the number of employees and raising productivity and profit.

Studies about the reality of Brazilian female entrepreneurs also provide evidence of barriers faced in their professional role. Difficulties of acceptance (Machado, 2002); lack of affective and social support (Carreira et al., 2001); difficulty in acting in the international market (Orser and Riding, 2000); difficulty of finance and absence of female entrepreneurs as reference models (Wilkens, 1989; Filion, 1999a; Filion, 2000) and precarious knowledge and lack of dedication to achieve success (Silveira et al., 2008). These results show a series of challenges, difficulties, prejudice, absence of education and resources. But they also reveal that female entrepreneurs who had the opportunity to develop skills and competencies, whether by means of training or not, fulfilled their objectives, despite the barriers and their limitations. It is further possible to observe that the micro/small firm segment, considered one of the pillars of the economy, performs an important role in the growth and maturity of a community, generating opportunities employing part of the labor force - women entrepreneurs and stimulus for business development (Leone, 1999). In order to better characterize the entrepreneurial action of women, it is necessary to study the peculiarities of each region, as what is considered a barrier in a certain place may not be in another. There are difficulties, but also, there are different ways of overcoming them for those who enter upon entrepreneurship. Thus, the question arises: which competencies contribute to the development of female entrepreneurs? This subject is discussed as follows.

\section{Competencies and entrepreneurial competencies}

The study of the competencies leads to understanding of a theme that has been very much discussed, as much in the academic milieu as in the business scenario. It has many facets and applications, and the models and practices related to competency are typically driven by the same aspirations, whose purpose is to achieve higher performance and financial profitability or success in the business (Spencer and Spencer, 1993). One of the main challenges in the literature about competency is the lack of consensus among scholars and the fact there exist many definitions of the term (Van Overveld and Van Goudoever, 1997; Brownell et al., 2006; Hoffmann, 1999; Hayton and McEvoy, 2006). Besides this, the terms: skill, expertise, talent and knowledge are inter-related, and at times, used in the literature as synonymous with competency (Smith and Morse, 2005). Concerning this aspect, Hayton and McEvoy (2006) suggest that, there is greater level of confusion about indiscriminate use of these terms with regard to competencies. They argue that competencies are interactional constructs and that these contemplate three parts: individual differences, definitions of the competencies that are socially constructed and forms of behavior that are situationally determined by performance criteria. Thus, the competencies are distinct because they do not depend only on the attributes of individuals, but also on the situation and social definition.

On the other hand, Le Boterf (1994) says that competency is not a state, but a process. This author considers that competent describes one who manages to mobilize and effectively put into practice the different functions of a system, covering resources as diverse as operations of reasoning, knowledge, activation of memory, evaluation, relational capacities or behavioral schemes. He further argues that competency is a knowhow acting responsibly and recognized by others, implying knowing how to mobilize, integrate and transfer knowledge, resources and skills in a particular professional context. Fleury and Fleury (2001) corroborate the concept and show that this meaning is broadened when applied in the context of transformations of the world of work, whether in companies or in society. In addition, they broaden the concept in the perspective that these aspects aggregate economic value to the organization and social value to the individual (Fleury and Fleury, 2001). Zarifian (1999) relates competency to the 
capacity of a person to assume initiatives, to go beyond the prescribed activities, to understand and master new work situations, to be responsible and be recognized for this. The author establishes that competency is the taking of initiative and assumption of responsibility by the individual in the professional situations that arise (Zarifian, 1999). In the understanding of Ruas (2000), the question of competency is placed in a space of interaction, on one the other, among persons and their respective know-how, and on the one hand, the demands of the organization. Thus, according to Feuerschütte and Godoi (2007), the development of competency presupposes autonomy, initiative and responsibility of the individual, consolidating the sense that it refers to a dynamic process associated to someone's voluntary action in the face of a complex professional situation, as recognized by the scholars cited previously.

The research conducted by Lerner and Almor (2002) with the use of a Likert scale applied to a sample of 220 Israeli business women demonstrated that, the managerial competencies (in finance, human resources, operations and strategy) are distinct from what he regards as entrepreneurial competencies (innovation and marketing). Mitchelmore and Rowley (2010) by means of a theoretical revision organized a chart with five categories of analysis of these competencies as follows: entrepreneurial (focus on innovation); businesses and managerial (focus on development of resources and operational and strategic aspects); human relations (focus on culture, leadership and persons); and conceptual and relationship (focus on communication, relationship with stakeholders and decision-making).

Other key competencies are associated to the role of entrepreneur. The recognition and exploitation of opportunities are concepts that distinguish the entrepreneur from the administrator (Shane and Venkataraman, 2000; Timmons and Spinelli, 2004), as entrepreneurs are capable of selecting opportunities of high quality in order to develop their businesses, disposition and will to work long hours (Hofer and Sandberg, 1987) and capacity for intense effort (MacMillan et al., 1985).

Baum (1994) developed a list of nine entrepreneurial competencies, based on works by Chandler and Jansen (1992) and Herron and Robinson (1993): knowledge, cognitive skill, self-management, administration, human resources, skill in taking decisions, leadership, recognition and development of opportunities; included too, are human relations and managerial practices. Broadening this scope, the study by Friedman et al. (1998) observes that, a growing number of entrepreneurs act under the presupposed equilibrium between work and personal life. They declare that such instances are complementary and not competitive in terms of priorities. This posture is recognized by the authors as win-win philosophy, with repercussions as much in the organization as in the personal lives of the entrepreneurs.
For Stolke (1980), it is not the physiological differences that explain the social hierarchies, but the social use that is made of them and the meaning attributed to them, upon studying the woman in the world of work and her competencies. This author further affirms that the equality between man and woman will not be guaranteed by the elimination of their differences. What is necessary is the elimination of class privileges and forms of hereditary domination, for which the maintenance of subordination of the women is as fundamental as the exploitation of work. One question that challenges the women seeking success concerns a search for equilibrium in their personal, family and professional lives. Such equilibrium implies that the perception of work and family benefit mutually helps the women; it also involves experiencing both demands in a positive manner, like a double challenge and not as a burden linked to the double working day that limits and constrains women (Jonathan, 2001).

Although, the term competency reflects different epistemological positions, it is worth stressing that its meaning is more and more present in people's lives and in professional activities. It is through different meanings that it is sought to align understanding of entrepreneurial competencies. In this research, Man and Lau's concept (2005) is utilized for entrepreneurial competencies. Man and Lau (2000) affirm that the competencies of the entrepreneur act as a bridge between the characteristics at individual level and the performance at company level. For these authors, the definition of competency is the total capacity of the entrepreneur to perform his/her professional role successfully. They propose ten areas of entrepreneurial competency: a) opportunity: considered a central point in the entrepreneurial process, involving the aspect of identifying an opportunity and developing it; b) organizational: those necessary to lead, control, monitor, organize and develop the internal and external resources, forming the capacities of the firm; c) strategic: aimed at the building of vision, definition of goals and formulation of strategies for the whole company; d) social: aimed at success in the contacts and partnerships, involving competencies of communication, persuasion and relations; e) commitment: to propitiate continuity of efforts regarding the businesses and established goals, as well as involving proactivity; f) conceptual: capacities for analytical thinking, learning, decision-taking, problemsolving, dealing with uncertainty, risk and pressure, response readiness and intuition; g) innovation: aimed at problem solving, innovative capacity and replication of the portfolio; h) relationship: linked to creation of a relationship network; i) learning competencies: refers to the capacity of entrepreneurs to learn how to learn, rendering themselves capable of undergoing ever more complex experiences via acquisition of new sets of knowledge; and j) competencies of work/personal life balance: part of the presupposition that there exists complementarity between these. 
The work by Man and Lau (2005), however, discusses entrepreneurial competencies without including gender distinction. This question, however, especially in emerging countries needs more development, as in, the literature researched; no conclusive results can be given about this theme. In this sense, this study seeks to understand which factors are decisive in starting up businesses, the obstacles and challenges encountered by female entrepreneurs in the southern region of Brazil, and above all, the competencies upon which they rely for conducting their activities. In this research, the dimensions presented by Man and Lau (2000) are broadened.

\section{METHODOLOGICAL PROCEDURES}

Following a qualitative approach, this research aims to understand a specific phenomenon in depth. Qualitative researches cover various forms of procedure to understand and explain the social phenomenon with the least possible distance from the natural environment (Godoy, 1995). The objective of the research is to analyze the entrepreneurial competencies that characterize women, with some financial limitations, when responding to quotidian challenges in their businesses, these being the result of their trajectories built throughout their social interactions. It also sought to understand the meaning of the challenges, obstacles and competencies upon which they rely in unexpected circumstances, without concern for enumeration and/or measurement of the events studied nor the generalization of the results. In this sense, the research is classified as exploratory. Therefore, the study adopts an epistemological interpretive position, seeking to explain the phenomenon under this study according to the point of view of the subjects researched, without imposing external points of view formulated a priori. For the researcher who adopts this type of method, according to Bogdan and Taylor (2000), it is fitting to adopt the meaning that persons give things and their surroundings. That is, they should seek to understand the phenomena that are being studied from the perspective of the participants.

The interviews of female entrepreneurs is involved with the construction of their own realities, they highlighted certain aspects of their individual experiences. The gathering of their trajectories was done by means of in-depth interviews, recorded with prior authorization of the participants, supported by a flexible questionnaire which allowed the interviewees to report their ideas and experiences freely. This set of questions was aligned with the objectives of the study, nature of the phenomenon studied and methodological and epistemological definitions of the research (Sierra, 2008). In qualitative researches, in general, an inductive focus is adopted. It means that the researchers make suppositions that are generated by the very process of research. And even though there is referential support in the discussion of the entrepreneurial competencies (Man and Lau, 2005), the interviews permit the emergence of other aspects that will be commented on throughout the process of analysis.

The data analysis relied on the techniques denominated analysis of content proposed by Bardin (1977) and the analysis of biographies and narratives proposed by Gibbs (2007). The analysis of content consists of a technique applicable to diverse discourses and all types of communication. It stems from the presupposition that behind the apparent symbolic polysemic discourse, there is hidden meaning to be disclosed. It can be adapted to an objectivist's perspective using a quantitative focus or following a qualitative tradition by means of which the researcher seeks to understand the characteristics, structures and/or models that permeate the messages taken into consideration. In this case, the effort made by the analyst is double. Understanding the sense of the communication as a normal receiver, and principally, diverting the viewpoint to seek another meaning, a possible message may be seen through or besides the first. Bardin (1977) referred to this activity as inference. The option in this study was to follow the qualitative approach given to the nature, objective and specificity of the data collected. It was intended to make a thematic analysis whose focus lies in the discovery of the nuclei of meaning that comprise the communication (Bardin, 1977). Thus, it was sought to understand these nuclei and the links among them.

The results were further supported in the analysis of biography and narratives, these being one of the fundamental forms with which people organize their understanding of the world. Through their histories, people make sense of their experiences and share them with others. For such, careful analysis of topics, content, style, context and the act of composing narratives, allows the understanding of the meaning of the fundamental events in their lives, likewise the entrepreneurial competencies necessary for the development of businesses, as well as the context and culture that permeate the lives of female entrepreneurs (Gibbs, 2007). The sample in a qualitative research does not obey rigid criteria. The choice of unit of analysis is basically determined by where the information and the phenomenon to be researched are located.

In this research, the units of analysis are the entrepreneurial competencies, and the discussions were founded upon the theoretical base already presented, as well as the analysis of content as the analytical resource validated in research qualitative nature, focused on the understanding and interpretation of the experiences of female entrepreneurs. Seven women who are participants in an entrepreneurship program held in the city of São Paulo, Brazil were interviewed. The program was specially designed for them with the objective of broadening and strengthening competencies that would aid them in the development of their businesses. It was part of a project of international scope, executed simultaneously in various countries and financed by an American bank. Due to the social nature of the program, the female participants had to fulfill some requisites such as not having sufficient income to pay for a similar course and not having studied in top business schools. Despite the financial limitation, the great majority of these women had concluded some advanced course in less recognized schools.

Of the group of 68 women, 7 were chosen to participate in this research. The choice was based on the fact each them presented a particular story. From humble backgrounds, they succeeded in overcoming difficulties and structured businesses with good growth prospects and characterized by a certain measure of innovation. Table 1 presents the profile of the research participants.

Table 1 provides evidence that the age range of the female participants is 36 to 46 , and the majority is married. The time they dedicated to work in companies before becoming entrepreneurs varies from 14 to 28 years. These data validate the state of being fed up with the corporate world mentioned by the respondents in the research. This signifies maturity in entrepreneurial decisionmaking and experience acquired before they assumed this career. These data corroborate the feelings revealed concerning the lack of space to grow in the corporative environment, and above all, the desire to seek independence and professional autonomy.

\section{ANALYSIS OF THE RESULTS}

After the literal transcription of the interviews, conducted in depth, with a semi-structured questionnaire, the responses were classified into three blocks: Category 1 decisive factors to start the business; Category 2 challenges and obstacles in the entrepreneurial career; and Category 3-competencies developed and under 
Table 1. Profile of participants.

\begin{tabular}{|c|c|c|c|c|}
\hline Female entrepreneurs & Age & Marital status & $\begin{array}{l}\text { Years service in a company } \\
\text { before becoming entrepreneur }\end{array}$ & Activity \\
\hline E1 & 46 & Married & 18 & Statistical analysis for Web \\
\hline E2 & 44 & Married & 28 & Publicity company on the web \\
\hline E3 & 43 & Single & 20 & Creation and production of gifts and binding \\
\hline E4 & 38 & Married & 14 & Personnel management consulting \\
\hline E5 & 46 & Single & 14 & Cultural producer \\
\hline E6 & 41 & Married & 25 & Training company for animal aesthetics \\
\hline E7 & 36 & Single & 16 & Information and communication technology agency \\
\hline
\end{tabular}

Source: Developed by the authors.

development throughout the trajectory. In order to preserve the identity of the female entrepreneurs interviewed, they are hereinafter referred to as E1 to E7.

\section{Category 1}

Contemplates the decisive factors in starting the business. The data reveal that, with unanimity, two factors were highlighted by the participants in the research: the fact of feeling saturated with the routine of the corporate world and the fact of desiring autonomy and conquering financial independence, illustrated as follows:

And I went on acquiring expertise, not only technical, but general professional... how to deal with persons, company regulations, I was learning all this. On the other hand, what happened in this corporative market was a tremendous pressure. And I am indocile and unsubordinable... besides this, if it's to work 12 hours per day... I'm going to work for myself [E1]

The environment was very heavy, much fierce competition, and then I decided to leave, because I no longer had that disposition to fight for things I had done before..., then I began to be more selective, and this ended up bothering me. I had no more patience to deal with corporative politics, no more patience for idiotic meetings that I used to attend willingly, but, after, you end up changing, you change your values [E2]

I was tired of doing the same things, I wasn't happy with my work... I had travelled, got to know some different things, learnt so much that when I returned to my company, I couldn't stay... it was difficult to bear that routine. So I thought why not work for myself [E3]

After a time dedicating myself to the corporate world, I noticed that my profile already no longer fitted into a company because I was bringing change, wanted to make changes, and in the company there was much resistance, and, as I seek information a lot, I have cultivated good relations, have a very large network... I decided that I would no longer work more for a company... I said to myself... enough, I can no longer remain in a company, and, for no money, will I ever return to work in one [E4].

l've worked in multinational companies, worked in the marketing area, developed some projects in multinational companies. And so, one day, I got tired, tired of being a bureaucrat... I didn't want to be one anymore, and decided that I would study and work for myself [E5]

Since the beginning of my career, l'd always reckoned I had to have my own business, a real entrepreneurial streak in me. I worked for many years in large scale multinationals, and I got tired of the routine... but in my first period of unemployment I said to myself... I'll open my own business... [E6]

The transition from corporate work to managing your own business is very difficult. There are many people who would like to make this change, and do not do so due to fear, because one is used to having a salary paid into one's account... and the consultant is subject to everything... today there is a lot, tomorrow nothing, then there's little, later there's an average amount. But, even so, in the corporate world, the hierarchic pressure of functions and results, causes insupportable stress, and when you create your own business, there's another type of stress, but you are the owner... there's much more pleasure [E7].

The aforementioned passages are evidence of the 
blossoming of the entrepreneur spirit, the desire and search for independence and financial autonomy, unlike what the corporate world offers, according to the female entrepreneur participants. Shane and Venkataraman (2000) suggest that, the recognition and exploitation of opportunities contribute to distinguishing the entrepreneur from the administrator. Bird (1988) supports this position, pointing out the need to observe the personal characteristics of the entrepreneurs, such as perseverance/ persistence as a fundamental characteristic for the development of a new enterprise, and that these characteristics, at times, encounter resistance in the corporate world. Besides these factors, others were explained as also being important in the process of the decision-making for a business start-up. These are: to go ahead with a dream in which one has always believed and have the profile for such; have a clear objective as to what one wants to achieve; work with what one likes to do; find space to launch one's ideas in the company, besides creating opportunities of employment for other persons. One of the questions raised in the quantitative analysis sought to identify the reasons for assuming an independent professional activity.

\section{Category 2}

Grouped responses to the challenges and obstacles encountered in the entrepreneurial career. The seven female entrepreneurs interviewed pointed out that the greatest challenge they had to cope with in the beginning of the venture was the courage to start businesses without money to invest, without finance, counting on their own capacities and expertise. Another relevant factor was the learning to take decisions alone and leaving the paradigm of earning a salary. On the other hand, they pointed out the obstacles, the fact of having to assume excessive taxation, bureaucracy and lack of government support, as the following illustrations reveal.

You only get finance if your business is running, making a profit and money. But, for the one who has the idea it's very difficult. I do not have this illusion of having to depend on finance, there has to be a plan B to put the business into operation and know how to face the formalities [E1]

We cannot count on finance, so we finance our company ourselves... with our own money. When it decapitalizes, it becomes very hard... the lines of finance in Brazil for small entrepreneurs are very bad... because they are extremely bureaucratic and one does not manage to understand the government bureaucracy... we have to pay an enormous quantity of taxes... [E2]

It is necessary to learn to take decisions in a male context... this is a great challenge... only with men.
Another point that deserves attention is the high taxes that we have to pay to run the business without money [E3]

The greatest challenge is to pioneer something new, and for this you have to have money... it's very difficult to count on government support and sources of finance. If your business does not attract investors, you need to count on yourself. You have to learn to work with risk... with your own resources [E4]

The great challenge in my area is the policy in the cultural area... it doesn't exist. There is a federal, state, and even municipal, law to give incentives... this has not worked for years. The state law permits tax deductions... but they allege... the money has run out, and at times, you are in the middle of the project. And, in turn, the federal law is in a process of change and you don't know what will come next. So, there are taxes to pay... all the time we're fighting for resources... we have difficulties with finance, and the big challenge in this scenario is to take decisions about what to invest in [E5]

The difficulty is centered around the lack of somebody to share the taking of decisions... what to invest in, when to invest, where to invest, for example. Taking decisions alone is a problem, as behind the decisions there's money, lack of support and very high tax rates to pay [E6]

The Brazilian entrepreneur pays a lot of tax... Brazil is acountry that supports the entrepreneur very little... the lines of finance are restricted with threatening interest rates... so, taking decisions about what to do needs much courage [E7]

The data showed aspects related to the lack of specific knowledge that provides security for the entrepreneur at the moment of creating the company, besides the general lack of support from class associations or even the government. It also presents the difficulties of access to finance, beside the high tax rates as problems to be confronted. It is worth stressing that, it is quite apparent, according to the research conducted in other emerging/developing countries that the reality of setting up businesses is not very different. K'Aol (2008) carried out research in Kenya with 300 female entrepreneurs. The data indicated the difficulty they cited in obtaining finance including the hostile environment for raising funds to develop their businesses. Another study by Tambunan (2009) in Indonesia had the objective of identifying the main barriers and motivations for female entrepreneurs running their businesses. The results pointed out four limiting factors to becoming an entrepreneur, such as, a low level of qualification allied to the lack of opportunity for capacitation, hindering the raising of resources to develop their businesses. The second factor is related to the conjugation of efforts between domestic and professional tasks; the third factor is the difficulty of 


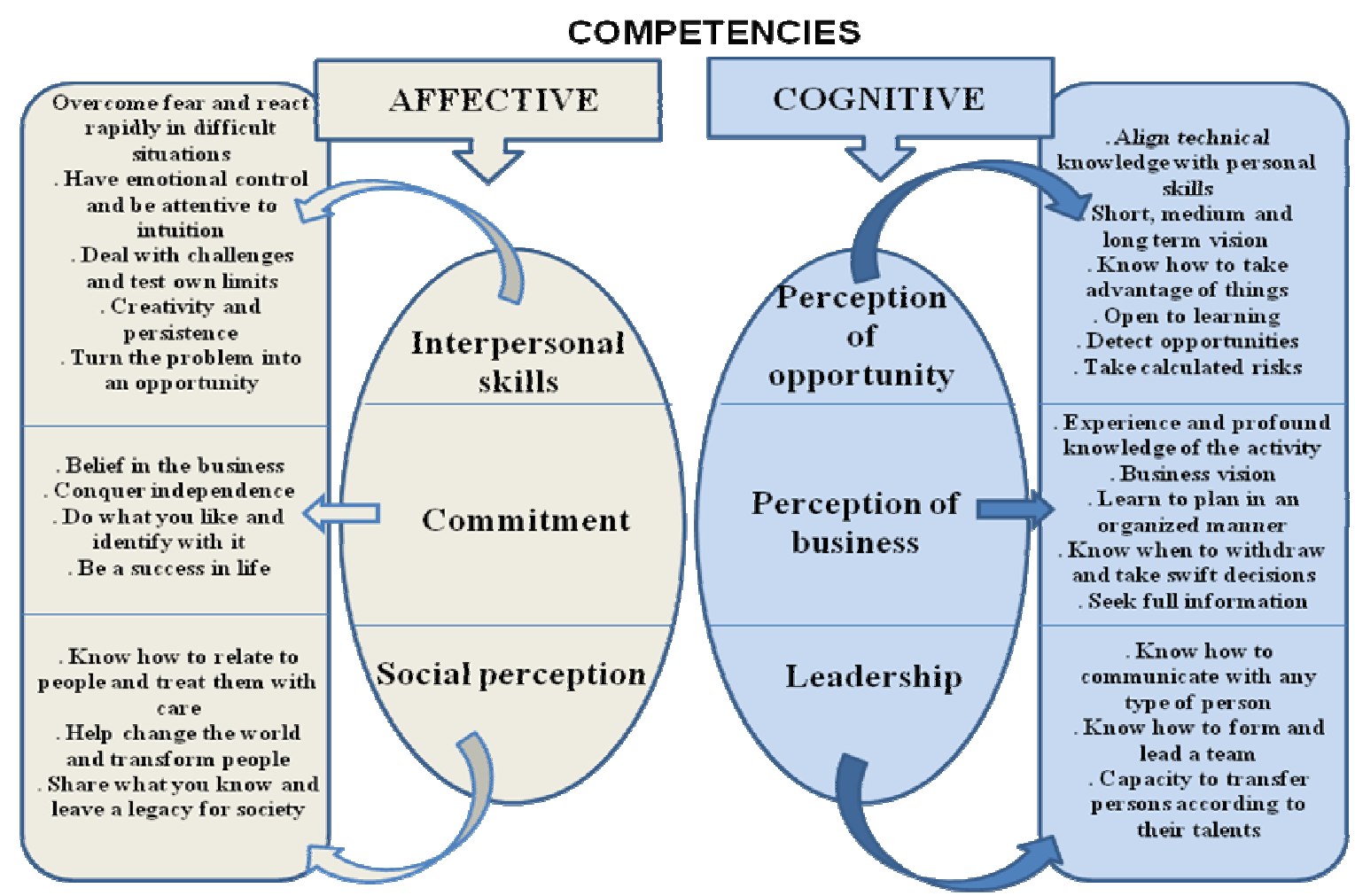

Figure 1. Identified competencies. Source: Developed by the authors.

expansion in the businesses arising from religious beliefs and traditions, and the fourth, but no less important, refers to the non-existence of sources of finance for female entrepreneurs in that country.

\section{Category 3}

Gathers together the competencies developed and under development throughout the entrepreneurial trajectory. This category seeks to respond to the central objective of this research. After in-depth analysis of the female entrepreneurs' responses, it was possible to distinguish cognitive and affective competencies, which effectively support the female entrepreneurs in the development of their businesses. Thus, these competencies were organized in Figure 1 and grouped by areas of competency.

The female entrepreneurs judge that they need to develop formal communication, learn to negotiate, and have proactive behavior, perfect ideas and relationships as well as improve their capacity to form partnerships. They consider it important to be prepared to deal with unexpected situations in their businesses, and for this reason, enhancement of creativity and confidence regarding being on the right track can be a step towards success. Other factors of relevance, more aimed at entrepreneurial action, concentrate on learning the know- how to make personnel accountable, make forecasts, earn money, and learn to say "No".

In general, as in Figure 1, the results of this research revealed that the female entrepreneurs clearly had a perception of their potentialities, limitations, desires and concerns within the scope of cognitive and affective competencies. In this sense, it seems that the female entrepreneurs in this research recognize the importance of developing the perception of opportunity, aligned to technical knowledge with personal skills, fundamental to the short, medium and long term view, to know how to take advantage of things and not miss opportunities that arise in their businesses and calculating the risks inherent to the operations. They attribute importance to the perception of business, to domination of the area of activity and the experience acquired throughout the activities.

In general, the data from this research are confluent in various aspects when compared with the competencies of Man and Lau (2005). For example, they all point out the importance of the recognition of opportunities for creation and development of the business, as well as, a sense of urgency in the item, innovation, formulation of strategies and commitment to the business. Female entrepreneurs greatly value the development of analytical thought, focus on innovation and predisposition to learn with aim of taking decisions which for Man and Lau (2005) are related with the conceptual competencies of 
innovation and learning. Other recurring data in the interviews are linked to the importance of establishing partnerships, developing relationships of trust thereby creating a social network that can bring results for their businesses. Man and Lau (2005) indicate these aspects when they discuss the relationship and social competencies. Finally, almost unanimously, they mention the importance of attempting to promote a balance between work and personal life pointing out that this still represents a challenge for females in charge of businesses.

They demonstrate prudence in withdrawing from uncomfortable situations, but the entrepreneurial spirit is aroused when they need swift and courageous solutions to overcome adversities in the market. Lastly, the need to apply the competencies of leadership, such as knowing how to communicate with people, irrespective of the type and hierarchical level, form and lead the team, besides shifting persons according to their talents. Regarding the affective aspects, it became clear that the interpersonal skills, such as overcoming fear, developing emotional control, dealing with challenges, being creative and persistent are essential for the survival of the business. Another aspect emphasized is commitment to the business which is characterized by belief in the business, conquest and independence, besides doing what they like, which contribute to being successful people in life in general. Although these aspects are fundamental, social perception also proves to be a decisive factor for the development of the business, in the sense of being careful with people and the environment that surrounds them, and seeking with their actions to leave a legacy for society.

\section{Conclusion}

The results obtained in this work are significant in three aspects. In the first place, the data from Category 1, confirms the results already found in other researches, for example, Bird (1988) and Shane and Venkataraman (2000), about the recognition and exploitation of opportunities that differentiate the entrepreneur from the administrator. In a certain way, even though researches on entrepreneurship have difficulty in finding consistency, this result points out the fact that in different contexts, the same profile of the entrepreneur is manifested. In the second place, the data obtained from Category 2 show that there are similarities in the difficulties faced by the Brazilian female entrepreneurs in relation to other emerging countries. This result shows that, regardless of the place, the women experienced similar situations for the creation of their own businesses, although the context and the experiences have significant differences. The research by Bertaux and Crable (2007), for example, corroborates these results with the evidence in relation to the day-to-day difficulties and restrictions, such as scarcity of resources, prejudices in relation to gender and cultural barriers, among others. On the other hand, similar to the results in this research, Bertaux and Crable (2007) obtained encouraging data about economic development, which, in some regions of the country, arises from the entrepreneurial activities of the women. Likewise, another research opined that even though people are confronted with problems relating to prejudices, education and absence of information among others, the desire to become financially independent contributes significantly to the decision to be an entrepreneur (Hossain et al., 2009). This Category also provides evidence that the challenges and obstacles experienced by the Brazilian female entrepreneurs are handled well when supported by affective and cognitive competencies that suffer the influence of cultural, sociopolitical and economic factors. In the third place, the results of this research broaden the concept of Man and Lau (2000) by including as fundamental entrepreneurial competency, affective aspects as in the model presented in Figure 1. It is evident that although fragmented in theory, these cognitive and affective aspects are indissociable in practice. Academic approaches that share this opinion (Goleman, 1995; Fineman, 2005) consider that the cognitive and emotional spheres complement each other and interpenetrate in such a way that the negation of any one of them will lead to an incomplete vision of the person in the context of work. The cognition of the individuals, in this sense, is influenced by their affects, and these, in turn, bear cognitive elements. Fineman (2001), however, stresses that, there are works that deal with the feelings that arouse passion, anguish, joy and boredom, among others, besides strengthening the idea that speaking about emotions in the context of businesses is part of the quotidian, as can be observed in the reports of the respondents in this research. It is admitted today that the affects influence the judgments made by persons, what they manage to retrieve from memory, the attributions accumulated through successes and failures, the creativity, the inductive and deductive reasoning (Damásio, 1994; Goleman, 1998), making inevitable the recognition that affective and cognitive processes are part of the work routine.

However, it would be necessary to study this aspect more deeply with the female entrepreneurs in Brazil, and also in other countries, as this category, which involves affective aspects, is an essential part of Brazilian culture. Besides this, it would also be interesting to deepen the discussion of Man and Lau about the matter of gender. The findings of this research reveal another point of great relevance, the fact the female entrepreneurs recognize that the opportunity they have obtained to participate in a capacitation program, contributed to a very great extent to the development of their competencies, and as a consequence, in the running of their businesses. These data corroborate the research by Botha et al. (2006) 
regarding the program entitled, Women Entrepreneurship Programme (WEP), whose results provide evidence that the female participants in the program developed skills and acquired new knowledge that helped them to run their businesses more effectively, increasing their confidence in themselves and their work, improving the number of collaborators, raising the productivity and profit of the company. By all accounts, the evidence found regarding qualifying people for the labor market, as much in the Brazilian researches as in those from abroad, suggests that these social actions can bear significant results for the business environments. It is a fact that competencies have been the target for inclusion or exclusion of professionals in highly competitive environments and also act as the requisites most evaluated by the business stakeholders.

Thus, it is expected to obtain results that can expand the categories of competencies and thus, broaden the knowledge in the area of entrepreneurial competencies, still incipient in the scientific literature.

\section{REFERENCES}

Amit R, Glosten L, Muller E (1993). Challenges to theory development in entrepreneurship research. J. Manage. Stud., 30(5).

Appelbaum SH, Audet, L, Miller JC (2003). Gender and leadership? Leadership and gender? A journey through the landscape of theories. Leadersh. Organ. Dev. J. Bradford., 24(1-2): 43.

Bardin L (1977). Análise de conteúdo, Lisboa: Edições.

Baum W Jr (1994). The relation of traits, competencies, vision, motivation, and strategy to venture growth. University of Maryland.

Beauchesne E (1999). Women entrepreneurs on rise. Kingston Whig Standard, Kingston, Ont.

Bekele JP (2008). Women entrepreneurship in micro, small and medium enterprises: the case of Ethiopia. J. Int. Women's Stud. Bridgewater, 10(2): 3-17.

Bertaux N, Crable E (2007). Learning about women. economic development, entrepreneurship and the environment in India: A case study. J. Dev. Entrep. Norfolk, 12(4): 467-12.

Bogdan R, Taylor S (2000). Introduction to qualitative research methods, New York: Wiley.

Botha M, Nieman GH, Van Vuuren JJ (2006). Evaluating the women entrepreneurship training programme: a South African study. Int. Indigenous J. Entrep., Adv. Strat. Educ. Tauranga, 2(1): 1-16.

Brownell J, Goldsmith M (2006). Meeting the competency needs of global leaders: A partnership approach. Hum. Resour. Manage., 45(3): 309-336.

Bygrave W (1989). The entrepreneurship paradigm (I): a philosophical look at its research methodologies. Entrep. Theory Pract., 14(1).

Bygrave W, Hofer C (1991). Theorizing about entrepreneurship. Entrep. Theory Pract., 16(2).

Carreira D, Ajamil M, Moreira T (2001). A Liderança feminina no século 21. SP: Cortez.

Chandler GN, Jansen E (1992). The founder's self-assessed competence the environment, and venture performance. Entrep. Theory Pract., 18(3): 77-89.

Danjou I (2002). L'Entrepreneuriat: Un champ fertile à la recherche de son unité. Revue Française de Gestion, 28(138): 109 -125.

Faraha N (2009). Critical factors of women entrepreneurship development in rural Bangladesh. Rajshahi University, Bangladesh Development Research Working, p. 5.

Feuerschütte SG, Godoi CK (2007). Competências empreendedoras: um estudo historiográfico no setor hoteleiro. Anais do $X X X I$ EnAPAND, Rio de Janeiro, Br.

Filion LJ (1999a). Empreendedorismo: empreendedores e proprietários- gerentes de pequenos negócios. Revista de Administração da Universidade de São Paulo. São Paulo, 3(2): 5-28.

Filion LJ (2000). O empreendedorismo como tema de estudos superiores. In: Empreendedorismo: ciência, técnica e arte. Brasília: CNI/IEL, 13(42).

Filion LJ (1999b). Diferenças entre sistemas gerenciais de empreendedores e operadores de pequenos negócios. Revista de Administração de Empresas - RAE. São Paulo, 39(4): 6- 20.

Fineman S (2001). A emoção e o processo de organizar. In S. R. Clegg, C. Hardy, and W. R NORD. Handbook de estudos organizacionais, 2: 157-189. (Atlas).

Fineman S (2005). Appreciating emotion at work: Paradigm tensions. International. Journal of Work Organizational and Emotion, 1:4-19.

Fleury A, Fleury MTL (2001). Estratégias empresariais e formação de competências: um quebra-cabeça caleidoscópico da indústria brasileira. São Paulo: Atlas.

Friedman S, Christesen P, Degroot J (1998). Work and life balance: the end of the zero-sum game. Harvard Bus. Rev., 76(6): 119-129.

Fundação Seade Dieese (2009). Departamento intersindical de estatística e estudos socioeconômico. Movimento Sindical Brasileiro. Brasília, Br.

Gartner W (1985). A framework for describing the phenomenon of new venture creation. Acad. Manage. Rev., 10(12).

Global Entrepreneurship Monitor (2008). Empreendedorismo no Brasil: relatório global, Paraná, IBQP e Sebrae.

Gibbs G (2007). Analyzing Qualitative Data. part of the Qualitative Research Kit, ed. U. Flick, Sage, London.

Gimenez F, Machado HV, Biazin CA (1998). The woman entrepreneur: a case study in the clothing sector. BALAS. South Padre Island. Proceedings.

Godoy A (1995). Introdução à pesquisa qualitativa e suas possibilidades. Revista de Administração de Empresas, São Paulo, 35(2).

Goleman D (1995). Emotional intelligence. New York: Bantam Books. P 384

Goleman D (1998). What makes a leader? Harvard Bus. Rev., 76, 93102.

Gomes AF (2004). O perfil empreendedor de mulheres que conduzem seu próprio negócio: um estudo na cidade de Vitória da Conquista. Revista Alcance. Itajaí, 11(2): 207-226.

Hayton JC, McEvoy GM (2006). Competencies in practice: An interview with Hanneke C. Frese. Hum. Resour. Manage., 45(3): 495-500.

Herron LA, Robinson RB Jr (1993). A structural model of the effects of entrepreneurial characteristics on venture performance. J. Bus. Venturing, 8: 281-294.

Hofer C, Sandberg W (1987). Improving new venture performance: Some guidelines for success. Am. J. Small Bus., 12(Summer): 11-25.

Hoffman A (1999). Institutional evolution and change: Environmentalism and the US chemical industry. Acad. Manage. J., 42: 351-371.

Hossain A, Naser K, Zaman A, Nuseibeh R (2009). Factors influencing women business development in the developing countries: Evidence from Bangladesh. Int. J. Organ. Anal. Bowling Green, 17(3): 202.

lakovidou O, Koutsou S, Partalidou M (2009). Women entrepreneurs in the Greek countryside: a typology according to motives and business characteristics. J. Dev. Entrep., Norfolk: 14(2): 165.

Instituto Brasileiro de Geografia e Estatística (2009). Censo Demográfico: pessoas responsáveis pelos domicílios. Disponível em $<$ http://www/ibge.gov.br>.

Instituto Ethos (2007). Perfil social, racial e de gênero das 500 maiores empresas do Brasil e suas ações afirmativas. São Paulo, Br.

Jonathan EG (2001). Mulheres empreendedoras: Quebrando alguns tabus, Anais CD-ROM, (No. 69), III Encontro Nacional de Empreendedorismo (ENEMPRE), UFSC, Florianópolis, Santa Catarina.

Joshi HG (2009). Institute of Chartered Financial Analysts of India (Hyderabad). The ICFAI, J. Entrep. Dev., Hyderabad, 6(2): 39.

K'Aol GO (2008). The role of microfinance in fostering women entrepreneurship in kenya. international council for small business (ICBS). World Conference Proceedings. Washington, 1: 14.

Le Boterf G (1994). De la compétence. Essai sur un attracteur étrange, Paris, Les Éditions d'Organisation, 16.

Leone NMCPG (1999). As especificidades das pequenas e médias 
empresas. Revista de Administração de Empresas, São Paulo, 34(2): 91-94.

Lerner M, Almor T (2002). Relationships among strategic capabilities and the performance of women-owned small ventures, J. Small Bus. Manage., 40(2): 109-125.

Machado HV (2009). Identidade de mulheres empreendedoras. Maringá: Eduem.

MacMillan IC, Siegel R, Narisimha SP (1985).Criteria used by venture capitalists to evaluate new venture proposals, J. Bus. Venturing, 1(1): 119-128.

Man T, Lau T (2000). Entrepreneurial competencies of SME, owner/manager in the Hong Kong services sector: a qualitative analysis. J. Enterp. Cult., 8(3).

Minniti M (2009). Foundations and Trends in Entrepreneurship. Hanover, 5(7-8): 497.

Mitchelmore S, Rowley J (2010). Entrepreneurial competencies: a literature review and development agenda. Int. J. Entrep. Behav. Res., 16(2): 92-111.

Moraes J (2008). A motivação da mulher e sua atuação no empreendedorismo social. In: V EGEPE. São Paulo, Br.

Novaes MDC, Ramos HR, Almeida MIR (2008). Mulheres empreendedoras no campo da pedagogia: criatividade, inovação e auto-eficácia a serviço da transformação social. Enanpad, Rio de Janeiro, $\mathrm{Br}$.

Orser B, Riding A (2000). An empirical study of gender challenges of exporting study for women-owned business. Disp.http://www.icsb.org/ pubs/2000/papers/index.

Ruas R (2000). Desenvolvimento de competências gerenciais e contribuição da aprendizagem organizacional, In:FLEURY MTL, OLIVEIRA JRMM (org.). Gestão estratégica do conhecimento: integrando aprendizagem, conhecimento e competências. São Paulo: Atlas.

Shane S, Venkataraman S (2000). The promise of entrepreneurship as a field of research. Acad. Manage. Rev., 25 (1): 217-226

Sierra $F$ (2008). Función y sentido de la entrevista cualitativa en investigación social. In: Cáceres, LJ G(coord.) Técnicas de investigación en sociedad, cultura y comunicación. México: Prentice Hall.
Silveira A, Gouvea ABCT, Hoeltgebaum M (2008). mulheres gerentes de micro e pequenas empresas de Santa Catarina, Brasil. EnANPAD, Rio de Janeiro, $\mathrm{Br}$.

Smith B, Morse E (2005). Entrepreneurship Competencies: Literature Review and Best Practies, Small Business Policy Branch, industry Canada, Ottawa.

Spencer L, Spencer S (1993). Competence at Work: Model for superior performance, Wiley, New York, NY.

Steyaert C (2007). Entrepreneuring as a conceptual attractor? A review of process theories in 20 years of entrepreneurship studies. Entrep. Reg. Dev., 19: 453-477.

Stolke V (1980). Mulheres e trabalho. In: Estudos CEBRAP: Trabalho e dominação, 26: 81-117.

Tambunan $T$ (2009). Women entrepreneurs in Indonesia: their main constraints and reasons. J. Asia Entrep. Sustain. Tauranga, 5(3): 37.

Timmons J, Spinelli S (2004). New venture creation - entrepreneurship for the $21^{\text {st }}$. century. New York: McGraw-Hill//rwin.

Ucbasaran D, Westhead P, Wright M (2001). The focus of entrepreneurial research: contextual and process issues. Entrep. Theory Pract., 25(4).

Van Overveld JAC, Van Goudoever B (1997). Competentiermanagement, in Vinke, R. H. W., Nijman, G., \& Simonis, A. (Eds), Jaarboek Personeelsmanagement, Kluwer Bedrjfsinfrmatie, Apeldoorn.

Wilkens J (1989). A Mulher empreendedora: como iniciar o seu próprio negócio. São Paulo: Mc-Graw-Hill.

Zarifian P (1999). Objectif competence. Paris: liaisons. 